\title{
DESTABILIZATION OF THE INTERNAL SITUATION AS ONE OF THE MAIN THREATS TO THE SECURITY OF RUSSIAN FEDERATION
}

For the first time internal security has been clearly articulated in Russian National Security Strategy of December 2015. That is when the so-called colour revolutions and "radical social groups which use nationalist and extremist religious ideologies, foreign and international non-governmental organisations, as well as private citizens who act against the Russian territorial integrity and destabilise political processes" have been deemed the most significant challenges to the Russian security, together with the North Atlantic Alliance and the United States of America. As a response to such defined threats, Russian legislation introduced solutions that attempt to prevent the danger. The aim of this article is to answer the question, whether Russian authorities treat the destabilisation of internal situation as one of the main challenges to the Russian security, and if yes, what are the indications of that? Does Russian legislation (especially from the last few years), actions of the Russian authorities and Russian subject literature, include evidence confirming this hypothesis? This article has been based on the analysis of the Russian National Security Strategy and legislation regarding the security. Additionally, Russian approach to defining security (including national security) has been analysed. The paper also describes how the perception of the said threats to the Russian security has been presented in Russian subject literature.

\section{SECURITY CATEGORY AND LITERATURE REVIEW}

Security category, translated from latin, is a state of no concern or anxiety (sine cura). It appeared in the works of philosophers and thinkers hundreds of years ago, yet security as a separate branch of science developed from international affairs in 20th century (as a result of the I World War) (Collins, 2015: 1). Since then, hundreds, if not thousands, of definitions have been formulated; however, the specific speculations on this topic are not subjects of this article. ${ }^{1}$ Security can be defined as a state (the subject is striving for the sense of security) or as a process (which aim is to assure the sense of security) (Koziej, 2011: 20) - in both cases the purpose is identical. Ian Bellamy is an example

${ }^{1}$ Overviews of definitions of security can be found in at least a few publications that sum up the research on the security category, e.g., Stańczyk (1996), Czaputowicz (1998), Collins (2015), Williams (2008). Whereas, the speculations over the concept and essence of security were carried out by, i.a. Konieczny (2012, Koziej (2011), Rosicki (2010), Piwowarski (2016), Hough, Malik, Moran, Pilbeam (2015), and others. 
of a researcher who defines security as a state. According to him, the security can be understood as a ,relative freedom from war, coupled with a relatively high expectation that defeat will not be a consequence of any war that should occur" (Bellany, 1981: 102). Whereas, an example definition of security as a process, is one by Stanisław Koziej: "a security of a given subject is the realm of their activity, which purpose is to assure the survival (existence) and freedom to fulfil one's own interests in a dangerous environment, especially through taking opportunities (favourable circumstances), facing challenges, reducing the risk, and countering (preventing and opposing) various types of threats to the subjects and their interests" (Koziej, 2011: 20).

The topic of security of modern Russian Federation has not been frequently undertaken in literature. Mainly cross-sectional studies which would characterise all or most the aspects of Russian security are missing. However, a lot of research has been carried out on the different types of security. In the last few years, many publications have been released on security in the context of The Arctic - predominant topics are the legal issues and possible militarisation of the territory (Flake, 2015; Kudinov, 2012, 2015; Ivanov, 2015; Yegorov, 2014; Mikhaylov, 2013). There are also plenty of works on the matter of economic, energy and food security of Russian Federation (e.g., Solov'Jov, Senchagov, 2015; Karanina, Sapozhnikova, Loginov, Holkin, Sergievskaya, Zurakhovskii, 2017).

Works related to the distinction between the national security and the state security constitute a separate category. Although, in Western World (including Poland) those concepts are used interchangeably, recognising the existence of national states, ${ }^{2}$ Russian subject literature includes discussions about the synonymic potential of both terms. A. S. Rogov and Y. G. Fedotova (2013) draw attention to the fact that between 1934 and 1992 only one concept of state security was in use; its meaning included economic, political and military (defence) security, along with others. ${ }^{3}$ Whereas, N. P. Gribin and A. V. Didenko (2010) point out that after the dissolution of the Soviet Union, the term state security was closely associated with the security of state and socialist society, therefore many authors replaced it with national security. Also today, in literature and legal documents (e.g., in Russian National Security Strategy), the term national security, which meaning is synonymous to state security, is much more commonly used. Occasionally, a wider meaning of the term national security is being emphasised, as it adds the security of society and the individual to the concept of state security.

\section{RUSSIAN NATIONAL SECURITY STRATEGY}

A new Russian National Security Strategy has been announced in the presidential decree $^{4}$ in December 2015. The update of strategy - the previous document had been

${ }^{2}$ In the Constitution of the Republic of Poland, the terms national security and state security are used synonymously.

3 The term national security was not in use, because its definition did not cover the multiplicity of ethnic group inhabiting the territory of Soviet Union. However, the term state security accurately emphasised the uniformity and integrity of USSR (Rogov, Fedotova, 2013).

${ }^{4}$ Russian Federation President's decree "On the Russian Federation's National Security Strategy" (No. 683) of 31 December 2015. 
issued in 2009 - has been carried out as a response to the Western World's actions after the Russian annexation of Crimea (i.a., economic sanctions), as well as the Federation's internal issues (i.a., economic crisis, anti-government protests). One of its main elements is the definition of national strategy, which is "the state in which an individual, society and state are protected from internal and external threats, and which assures the rights and freedoms of the citizens of the Russian Federation, decent quality and standard of life, sovereignty, independence, state and territorial integrity, as well as a stable social-economic development of the Russian Federation. National security comprises state defence and all types of security foreseen in the Constitution of the Russian Federation and in Russian Federation's acts, mainly national, social, informational, ecological, economic, transport and energy security, as well as the security of an individual" (Ukaz, 2015).

In following parts, the authors of the strategy distinguish the main challenges to the security of Russia, and point out the objects that can either directly or indirectly threaten the security. Firstly, the document emphasises the dangers coming from the United States of America and their allies, which try to pressure Russia in various ways, e.g., politically, economically or militarily, through striving to maintain their dominance in global matters. Secondly, North Atlantic Alliance's activity poses a threat to the national security of Russia, especially - according to the authors of the strategy - strengthening of its military potential and further expansion of its influence, particularly near the Russian borders. Additionally, the strategy includes accusations against the United States of America and European Union, which by imposing an overthrow contradictory to the Constitution of Ukraine, led to the outbreak of military conflict in Eastern Ukraine and to the destabilisation near the border with Russia (Dekret, 2015).

Apart from directly indicating the entities threatening the security of Federation, strategy's authors point out phenomenons which could potentially be dangerous to the internal situation of Russia. Main focus is drawn to "the practice of overthrowing legal political regimes, provoking instability and intra-state conflicts" (Dekret, 2015) which has lately been gaining popularity. Additionally, terrorism and the use of economic policy tools for political purposes have been deemed dangerous. Threats related to the development of new technologies and information (e.g., disinformation policy, creation of false profiles, information theft, etc.) are also being mentioned among other perils. One of the most thoroughly described risks is the one related to the activity of terrorist and extremist organisations, as well as other various associations (mainly those funded externally) which main objective is violation of the unity of Russia's integrity, stability of its system and "violation of traditional Russian moral-spiritual values" (Dekret, 2015).

In the Russian National Security Strategy, close attention has been paid to the threats related to the economic sphere. Apart from listing the issues which Russian economy has been facing for many years (low competitiveness, high dependance on natural resources, informal sector, corruption), the authors of the strategy also mentioned that Russian economy is threatened by the actions of other members of the international economic system (for example, Western economic sanctions introduced after the annexation of Crimea) and by the regional and global economic crises, which cause instability of the system (Dekret, 2015). 
Russian National Security Strategy primarily focuses on recognising main threats; however, the most extensively characterised are those related to the external security, internal system stability and integrity of the state's territory and the society. Naturally, the document also includes paragraphs devoted to education, science, culture and healthcare; nonetheless, in these spheres, Russian strategies remain unchanged for years.

\section{DESTABILISATION OF THE INTERNAL SITUATION AS A THREAT TO SECURITY}

Yefanova (2010) in his theoretical and terminological speculations proposes a connection of the security category with the concept of stability. Ensuring stability, i.e., internal longevity of state and its international surroundings is inseparably associated with assuring the safety of state. Three levels or types of stability can be distinguished: first is the stability of the military-political state leadership (permanent composition, legally defined terms of office). Second level concerns the stability of the political regime (maintaining current social-political system, evolutional nature of political changes, no political violence). While the third is the stability of the community, people (maintaining the territorial integrity of state, assuring the personal safety and well-being of citizens, improving environmental protection and sustaining a demographic balance) (Yefanova, 2010). A consequence of merging the security category with stability category is the acknowledgement that instability of one of the levels results in the loss of state security, or at least in its imbalance.

Protection against foreign agent

After mass anti-government protests on the turn of 2011 and 2012 and the Euromaidan, which began in Ukraine at the end of 2013 and ended in 2014, Russian legislative system introduced at least a few new regulations, which aim was to ensure the stability of the system and eliminate the possibility of jeopardising its functioning. The changes, which are thought to be preventive to the potential destabilisation of internal situation in Russia, are the introduced in 2012 modifications to the federal law on nonprofit organisations. This amendment introduced a concept of "foreign agent" to the Russian law system; these are the non-governmental organisations that use external financial help. Limitations apply to those subjects which operate within the political sphere (including political actions and those that shape public opinion). Obligatory registration of non-governmental organisations (registry of foreign agents carried out by the Ministry) is a direct result of these regulations, but also an obligation to label all their publications and other works with "foreign agent." Additionally, the organisations which are considered "foreign agents" are subjects to further, detailed controls (especially financial), and have been obliged to issuing activity reports more often. ${ }^{5}$

${ }^{5}$ As a result of the controls, 126 organisations were on the list of "foreign agents" in April 2016; among them Moscow's Centre of Social and Workers' Rights (Centum Praw Socjalnych i Pracowniczych), Kaliningrad's Human Rights Centre (Centrum Praw Człowieka), Moscow’s Civic Education School (Szkoła Edukacji Obywatelskiej) and Institute of forecasting and solving political conflicts from Nizhny Novgorod (Svedeniya reyestra NKO). In 2014, GOLOS association, which protects 
A failure to comply with the above-mentioned regulations can result in severe financial penalties, and in special cases, in imprisonment of its representatives (Federal'nyy zakon).

A protection of the internal security of the state was a justification for the introduction of laws regarding externally funded non-governmental organisations. Sergey Markov (Russian politic, political scientist, State Duma's deputy) admitted that the law's aim is to lower the influence of other countries on state's politics. Moreover, he acknowledged the leniency of the law in comparison to that of the United States' ${ }^{\prime 6}$ and decided that it should be recognised that everyone involved in politics wants to take over the power, hence externally funded entities should inform the society about their source of finance. If someone does not want to obey the new law, then, according to S. Markov, either works contrary to the Russian interests or wants to steal money given by foreign governments to fund non-governmental activities (Sinkin, 2012). In opinion of Russian political scientists - Tavmasyan and Rakitin (2017) - in times of high popularity of hybrid warfare and involvement of foreign agents in internal conflicts of other countries (e.g., Ukrainian Revolution of 2013/2014), as well as possible influence of external forces on the society's awareness, state's control over organisations financed from abroad is an important element to the security strategy of Russia.

In relation to the changes in law on non-profit organisations, many critical voices arose; especially in relation to the negative reception of "foreign agent" by Russian society (it is associated with an idea of a spy, an agent from abroad, someone who is a threat to the safety and security of the state). Also, a vast majority of non-governmental organisations that deal with the protection of human rights (what, according to Russian authorities, can be classified as political activity) are funded externally, because no Russian firm would support an activity which premise is to act against the state or its administration. ${ }^{7}$ Ресурсный правозащитный центр (Human Rights Resource Center), a Russian organisation providing information and legal aid to nongovernmental entities, created a report which analyses the effects of the changes in the

voters' rights, has been forcibly put on the foreign agents list. Previously, the association refused to voluntarily put itself on the list, for which it has been penalised with a fine. A permission to forcibly place foreign agents on the list has been granted to the Russian Federation Ministry of Justice through the amendment to the law on non-profit organisations signed by President V. Putin in June 2014. In order to be placed on the list, a court ruling is not necessary. An organisation can appeal against the decision (Rosja. Golos).

${ }^{6}$ Foreign Agents Registration Act, FARA, has been passed in the United States in 1938 in order to expose (only registration was required) political and quasi-political organisations that were connected with foreign governments in any way (mainly financially). At that time, the act was meant to counter the expansion of nazi propaganda in pre-war America. Now it is used to register entities, which practice lobbying for other countries. It mostly pertains to activities of law firms and PR companies, not non-governmental organisations controlled by the Russian version of the law. In 2017 the Department of Justice, by the virtue of FARA, demanded registration of a worldwide television station Russia Today (RT) as a foreign agent financed by the Russian government of (Lusher, 2017). Russian authorities protested agains such actions of American administration.

7 According to Lyudmila Alexeyeva - chairwoman of the Moscow Helsinki Watch Group - over $90 \%$ of non-governmental organisations that deal with protection of human rights in Russia find funding abroad, since there is a lack of businesses that are not afraid of providing money to such entities. Currently there is no solution to this issue, unless more private companies, which are not scared of authorities, start operating in Russia. (Pravozashchitnitsa). 
law on non-profit organisations. The research showed that Russian authorities broadly define organisations operating in a public sector, hence a significant number of them fell under the introduced restrictions. Any information about their activities shared online and in media, or their representatives taking part in public events are enough to be restricted by the new law ("Inostrannyye agenty»). As a result, there is a decrease in society's trust for the non-governmental organisations, and in willingness to devote their time to such activity.

\section{UNDESIRABLE ORGANISATIONS}

A 2015 act on undesirable organisations (or actually a group of amendments to the already functioning laws) perfectly suits the narrative of the necessity to protect Russian Federation's national security. It enables forbidding operations of foreign and international organisations on Russian Federation's territory without trial (Putin podpisal zakon). According to the act, a foreign or international organisation is deemed undesirable when it poses a threat to the foundation of the Russian system, its defence and security. As a consequence, the law prohibits such organisations from disseminating information through media (also Internet), and creating new entities; it also imposes strict monitoring of the already existing units. Additionally, working for such organisation can be punishable by up to 100,000 rubles, and, in special cases, even up to 6 years in jail (Putin podpisal zakon). The act allows Russian authorities to block the accounts of undesirable organisations and repress Russian organisations that work with those entities (an obligation to issue activity reports) (Putin podpisat).

According to the authors of the law - Aleksander Tarnawski (A Just Russia) and Anton Ishchenko (Liberal Democratic Party of Russia) - in the act they should be considered as a necessary precautionary measures that are assumed to protect the foundations of constitutional system, national interests, due rights and interests of citizens, and security of the state (Zamahina, 2015). Essential, in this case, is precautionary security procedure - removal of entities that could, even potentially, support opposition in Russia. It is supposed to protect the Federation from incidents, such as those that took place in Ukraine. However, realistically evaluating the situation, this law again will hinder the functioning of entities that operate independently from authorities. It does not only concern the foreign organisations explicitly mentioned in the act, but also Russian entities that ever cooperated or received support (not necessarily financial, but for example expertise or problem solving) from foreign organisations. After the first two years, it is noticeable that the restrictions mainly affected organisations that support the growth of democracy and civil society. ${ }^{8}$ The authorities of Russian

${ }^{8}$ In 2018, on the list of foreign and international non-governmental organisations, which activity is deemed undesirable in Russian Federation, were i.a., National Endowment for Democracy (organisation promoting democracy abroad), OSI Assistance Foundation (organisation financially supporting democratic reforms, protection of human rights, access to information and economic development), Open Society Foundation (organisation that promotes democracy, human right and open society), The U.S. Russia Foundation for Economic Advancement and the Rule of Law (organisation supporting the growth of market economy in Russia), National Democratic Institute for International Affairs (organisation supporting the efficiency of democratic institutions) and Open Russia Civic 
Federation considered actions inspired and funded from abroad are dangerous to the internal security of their country.

\section{NATIONAL GUARD PROTECTING STATE SECURITY}

In order to guarantee security of Russia and counteract the destabilisation of the internal situation, a new formation have been appointed in April 2016 - National Guard of Russia. A group of few hundred thousand professionally trained soldiers (it is estimated - there are no official statistics - that in 2016 it included 170 thousand soldiers at its disposal, but the number can ultimately reach 300 thousand (Veroyatnuyu) replaced conscription of the Ministry of Internal Affairs of the Russian Federation, and took over the responsibilities of special police forces: (Special Purpose Police Unit) and SOBR (Special Unit [with/for a] Quick Reaction). Officially, the National Guard of Russia is a military organisation created to ensure national and public safety, protection of human rights and freedoms. ${ }^{9}$

A creation of specialised and dependent on the Russian President National Guard appears to be a natural consequence of the Russian National Security Strategy of 21 December 2015. As previously mentioned, this document, more than its previous version from six years ago, laid out the internal issues and threats to the security of Russia. Although NATO and the United States were pointed out as the main enemies (North Atlantic Alliance being an extension of USA's activity), potential "colour revolutions"10 and "radical social groups that implement nationalist and extremist religious ideologies, foreign and international non-governmental organisations, as well as private citizens who work against the territorial integrity of Russia and destabilise political processes" (Czerniewicz, 2016) were also considered challenges to the Russian security. Such defined threats perfectly fit into the job description of National Guard (with an emphasis on "fighting extremists" that are radical social groups, but also ordinary citizens who publicly criticise the power). Moreover, the new security strategy, more often than the previous one, refers to the collective values (public order, country's integrity, independence of political entity, instead of the growth of individual, its rights and freedoms) (Dekret, 2015), which are meant to be protected by the National Guard. Viktor Zolotow - Director of the National Guard - also addressed the internal security category and protection against numerous threats (economic crisis, terrorism, migration). ${ }^{11}$ Hence it appears reasonable to qualify the emergence of the new formation as one of the elements of the system of strengthening the Russian Federation's internal security.

Movement (organisation that promotes democracy and human rights in Russia, founded by M. Khodorovsky) (Perechen'inostrannykh).

9 The definition has been included in the Federal Act of 3 July 2016 "O voyskakh natsional'noy gvardii Rossiyskoy Federatsii" passed by the State Duma (22 June 2016) and Federation Council (29 June 2016) and approved by the President of Russian Federation.

${ }^{10}$ In Russia, colour revolutions are uncontrollable outbreaks of social rebellion aimed at changing the power or political system.

${ }^{11}$ During Zolotowv's raport presentation at Federal Council entitled: O sostoyanii i perspektivakh stroitel'stva voysk natsional'noy gvardii Rossiyskoy Federatsii na srednesrochnuyu perspektivu (Direktor). 


\section{ANTI-TERRORIST LAWS}

Counter-terrorism bill passed in $2016^{12}$ (also called Yarovaya bill, from the name of Irina Yarovaya - State Duma's deputy - who, together with Viktor Ozerov, submitted the bill) was created to counter potential threats to the Russian national security. The bill included regulations, which increase penalties for social media activity, considered terrorist-related by the law enforcement authorities. After amendments, online activity is classified similarly to media activity. These regulations also introduce restrictions on leaving the country for people convicted of particular crimes (mainly terrorist and extremist crimes ${ }^{13}$ ), rise penalties for participation in organising mass riots, and introduce the possibility for security services to inspect private correspondence and phone calls of people on Russian territory. ${ }^{14}$ Russian literature includes discussions, in which extremism is considered one of the biggest threats to the security of Russia. Volosyuk (2014) warns that extremism should not be treated as a marginal phenomenon, but as a powerful occurrence of organised crime with clearly defined political objectives, which can only be achieved through violence. Whereas, Magomedov, Krotov, Samygin (2016) consider extremism - next to corruption - as one of the greatest threats to the security of Russian Federation. New legislation proves that country's authorities identified the danger and decided to counteract.

\section{SUMMARY}

After the experiences of Arab Spring, Euromaidan and mass post-election protests (2011/2012), in the biggest Russian cities the authorities started paying more attention, in their actions and new legislation, to the issue of internal security. Potential destabilisation of internal situation has been defined as one of the greatest threats to Russian security. Instances of that can be found mainly in the Russian National Security Strategy amended in 2015, where the possible internal dangers have been meticulously characterised. As a response to the strategy's evaluations, Russian legislative system introduced laws, which aim at preventing these potential threats. The purpose of the law which introduced the concepts of foreign agent and undesirable organisations, is to forestall possible interference into the political system and public space of Russian

${ }^{12}$ Some of the amendments introduced by this bill, i.a., the new obligations imposed on telecommunications companies (storing call registers and all correspondence of the network's users), have been postponed due to the unreadiness of mobile network providers. Members of the telecommunication market criticised introduced regulations, mainly because of the compulsion to prepare new infrastructure and high cost of its maintenance (Dukhanova, Chursina, 2018).

${ }^{13}$ A concept of extremist activity is very unclear in Russia. At the beginning of 2018, Michaił Listow's case has been heavily discussed on Russian social media, who two years later on his Vkontakte profile shared a well-known photo of Moscow Victory Parade of 1945 (the photo depicted Red Army soldiers, throwing Nazi flags on the ground). When M. Listow engaged in the campaign for Alexei Navalny, police initiated proceedings against him, and accused him of publicly demonstrating Nazi symbols based on that photo. Listow has been considered extremist by the judge (what significantly impedes life in Russia) and punished with a fine (Nawalny, 2018).

${ }_{14}$ Majority of the changes introduced by Yarovaya bill have been discussed in the analysis prepared by the journalist of Meduza news page (Najbardziej drakońskie). 
Federation from abroad. A main objective of the new formation - National Guard - is defending the stable internal situation and foundations of its existence. Also, the newly introduced anti-terrorist laws are meant to prevent the potential dangers to the national security; however, critics of the introduced resolutions point out that a significant limitation of operating space for citizens' initiatives and organisations which aim at development of the civil society, are the results of the new regulations. Hence, it can be said that Russian authorities fear not only the destabilisation of the internal situation stimulated from abroad (e.g., through other countries' operations), but also by their own citizens, who could potentially desire a change in the Russian political system. Such enemy has been targeted with multidimensional solutions, mainly legal, but also military.

\section{REFERENCES}

Bellamy I. (1981), Towards a Theory of International Security, „Political Studies”, 29/1.

Collins A. (2015), Contemporary Security Studies, Oxford University Press.

Czaputowicz J. (1998), System czy nieład? Bezpieczeństwo europejskie u progu XXI wieku, WNPWN, CSM, Warszawa.

Czerniewicz K. (2016), Konfrontacji ciag dalszy. Co mówi rosyjska strategia bezpieczeństwa, Ośrodek Analiz Strategicznych, https://oaspl.org/2016/02/16/konfrontacji-ciag-dalszy-comowi-rosyjska-strategia-bezpieczenstwa/ (29.09.2017).

Dekret Prezydenta Federacji Rosyjskiej z dnia 31 grudnia 2015 r., No. 683, O strategii bezpieczeństwa narodowego Federacji Rosyjskiej https:/poland.mid.ru/web/polska_pl/koncepcja-politykizagranicznej-federacji-rosyjskiej/-/asset_publisher/x9WG6FhjehkG/content/id/23299928 (12.12.2017).

Direktor Rosgvardii general armii Viktor Zolotov vystupil v Sovete Federacii (2017), http://rosgvard. $\mathrm{ru} / \mathrm{ru} /$ news/article/direktor-rosgvardii-general-armii-viktor-zolotov-vystupil-v-sovete-federacii (23.02.2018).

Dukhanova P., Chursina M. (2018), Taym-aut dlya zakona: pravitel'stvo obsuzhdayet ot:srochku vstupleniya v silu paketa Yarovoy, https://russian.rt.com/russia/article/472028-paket-yarovoipravitelstvo-otsrochka (22.02.2018).

Federal'nyy zakon O nekommercheskikh organizatsiyakh ot 12.01.1996, N 7-Ф3.

Flake L. E. (2015), Forecasting Conflict in the Arctic: The Historical Context of Russia's Security Intentions, „The Journal of Slavic Military Studies”, Vol. 28(1).

Gribin N. P., Didenko A. V. (2010), Kontseptual'nyye osnovy natsional'noy bezopasnosti Rossiyskoy Federatsii.

Hough P., Malik S., Moran A., Pilbeam B. (2015), International Security Studies: Theory and Practice, London-New York.

«Inostrannyye agenty»: mificheskiye vragi i real'nyye poteri rossiyskogo obshchestva (2015), Resursnyy pravozashchitnyy tsentr, http://ihahr.org/sites/default/files/files/hrrc-report-on-fango.pdf (22.02.2018).

Ivanov G. V. (2015), National security of Russia in the Arctic: Problems and solutions, „Vestnik MGTU”, Vol. 18(3). 
Karanina E., Sapozhnikova E., Loginov D., Holkin A., Sergievskaya E., Zurakhovskii A. (2017), National aspects of food security of Russia, MATEC Web of Conferences, Vol. 106.

Konieczny J. (2012), O pojęciu bezpieczeństwa, „Bezpieczeństwo. Teoria i Praktyka”, No. 1(VI).

Koziej S. (2011), Bezpieczeństwo: istota, podstawowe kategorie i historyczna ewolucja, „Bezpieczeństwo Narodowe", No. 18.

Kudinov N. N. (2012), Making Provision for Russia's National Security in the Arctic's Maritime Border Zone, „Russian Politics \& Law”, Vol. 50(2).

Kudinov N. N. (2015), The Coast Guard Federal Security Service of Russia and protection of marine economic activities in the Arctic, „Vestnik MGTU”, Vol. 18(3).

Lusher A. (2017), Russia Today affiliate ordered by US government to register as 'foreign agent' under anti-propaganda laws, „Independent”, 12.09.2017, http:/www.independent.co.uk/news/ world/americas/us-politics/russia-today-sputnik-us-foreign-agent-rt-news-affliate-kremlinmoscow-putin-anti-propaganda-fara-a7943131.html (21.02.2018).

Magomedov M. G., Krotov D., Samygin S. I. (2016), Korruptsiya i ekstremizm kak glavnye ugrozy natsionalnoy bezopasnosti, „Gumanitarnye sotsialno-ekonomicheskie i obschestvennye nauki”, No. 12, http://cyberleninka.ru/article/n/korruptsiya-i-ekstremizm-kak-glavnye-ugrozy-natsionalnoy-bezopasnosti (23.02.2018).

Mikhaylov D. A. (2013), O nekotorykh voprosakh obespecheniya kompleksnoy bezopasnosti Arkticheskoy zony Rossiyskoy Federatsii, ,Strategiya grazhdanskoy zashchity: problemy i issledovaniya", 3 (1).

Najbardziej drakońskie projekty od lat. Co zawiera i czym grozi „pakiet Jarowej”? (2016), http:// freerussia.eu/2016/06/23/pakiet-jarowej/ (22.02.2018).

Nawalny A. (2018), Aktsiya protiv idiotizma, https://navalny.com/p/5745/ (22.02.2018).

Perechen' inostrannykh i mezhdunarodnykh nepravitel'stvennykh organizatsiy, deyatel'nost' kotorykh priznana nezhelatel'noy na territorii Rossiyskoy Federatsii, http://minjust.ru/ru/activity/nko/unwanted (23.02.2018).

Piwowarski J. (2016), Nauki o bezpieczeństwie. Zagadnienia elementarne, Kraków.

Pravozashchitnitsa L. Alekseyeva nazvala zakon ob NKO “idiot·skim” (2012), http://monavista.ru/ news/pravozaschitnica_l.alekseeva_nazvala_zakon_ob_nko_idiotskim/ (22.02.2018).

Putin podpisat "ustawę o niechcianych gościach" (2015), http://www.rp.pl/article/20150523/ SWIAT/305239917\#ap-1 (06.07.2017).

Putin podpisal zakon o «nezhelatel'nykh» organizatsiyakh (2015), http://www.novayagazeta.ru/ news/1694019.html (06.05.2017).

Rogov A. S., Fedotova Y. G. (2013), Gosudarstvennaya bezopasnost': element ili soderzhaniye natsional'noy bezopasnosti Rossiyskoy Federatsii, „Vlast'”, No. 12, http://cyberleninka.ru/ article/n/gosudarstvennaya-bezopasnost-element-ili-soderzhanie-natsionalnoy-bezopasnosti-rossiyskoy-federatsii (18.02.2018).

Rosicki R. (2010), O pojęciu i istocie bezpieczeństwa, „Przegląd Politologiczny”, No. 3.

Rosja. Gołos przymusowo wpisany do rejestru "zagranicznych agentów” (2014), http://wyborcza. pl/1,91446,16124346,Rosja_Golos_przymusowo_wpisany_do_rejestru_zagranicznych. html (27.04.2017).

Sinkin O. (2012), Pravozashchitniki v yarosti. Rossiya perenyala opyt SSHA v kontrole za NKO, https://sever248.wordpress.com/tag/\%D0\%BD\%D0\%BA\%D0\%BE/ (21.02.2018).

Solov'Jov A. I., Senchagov V. K. (2015), Global risks and the economic security of Russia: problems of management, „Sovremennye Tehnologii Upravleniâ”.

Stańczyk J. (1996), Wspótczesne pojmowanie bezpieczeństwa, ISP PAN, Warszawa. 
Tavmasyan A. Y., Rakitin Y. A. (2017), Nekommercheskye organizacji, vypolnyayushche funkcji inoctrannovo agenta kak ugroza nacionalnoy bezapacnocti Rossii, „Ростовский научный журнал", http://rostjournal.ru/?p=2284 (21.02.2018).

Ukaz prezidenta Rossiyskoy Federatsii O Strategii natsional'noy bezopasnosti Rossiyskoy Federatsii ot 31 dekabrya 2015 g., No. 683.

Veroyatnuyu chislennost' Natsgvardii v Rossii otsenili v 300 tys. chelovek (2016), http://www.interfax.ru/russia/502568 (23.02.2018).

Volosyuk P. V. (2014), Ekstremizm kak sovremennaya ugroza rossiyskomu obschestvu i gosudarstvu, „Gumanitarye i yuridicheskije issliedovania”, No. 4, http://cyberleninka.ru/article/n/ekstremizm-kak-sovremennaya-ugroza-rossiyskomu-obschestvu-i-gosudarstvu (23.02.2018).

Williams P. D. (2008), Security Studies: An Introduction, in: Security Studies: An Introduction, (ed.) P. D. Williams, London-NewYork.

Yefanova Y. V. (2010), Natsional'naya bezopasnost' Rossii: teoreticheskiye i terminologicheskiye aspekty, ,Vestnik Volgogradskogo gosudarstvennogo universiteta. Seriya 4: Istoriya. Regionovedeniye. Mezhdunarodnyye otnosheniya", (1): 151-156.

Yegorov A. A. (2014), Voyenno-politicheskoye znacheniye Arkticheskogo regiona Rossii, „Vlast””, No. 9.

Zamahina T. (2015), V RF sozdadut spisok nezhelatel'nykh inostrannykh organizatsiy, https:// rg.ru/2015/01/20/spisok-site.html (22.02.2018).

\begin{abstract}
For the first time internal security has been clearly articulated in Russian National Security Strategy of December 2015. That is when the so-called colour revolutions and "radical social groups which use nationalist and extremist religious ideologies, foreign and international nongovernmental organisations, as well as private citizens who act against the Russian territorial integrity and destabilise political processes" have been deemed the most significant challenges to the Russian security, together with the North Atlantic Alliance and the United States of America. As a response to such defined threats, Russian legislation introduced solutions that attempt to prevent the danger. The aim of this article is to answer the question, whether Russian authorities treat the destabilisation of internal situation as one of the main challenges to the Russian security, and if yes, what are the indications of that? Does Russian legislation (especially from the last few years), actions of the Russian authorities and Russian subject literature, include evidence confirming this hypothesis?
\end{abstract}

Keywords: Russia's security; national security, Russia's security strategy, non-governmental organizations, National Guard

\title{
DESTABILIZACJA SYTUACJI WEWNETRZNEJ JAKO JEDNO Z GLÓWNYCH ZAGROŻEŃ BEZPIECZEŃSTWA FEDERACJI ROSYJSKIEJ
}

\section{STRESZCZENIE}

Bezpieczeństwo wewnętrzne po raz pierwszy wyraźnie wyartykułowane zostało w Rosyjskiej Strategii Bezpieczeństwa Narodowego z grudnia 2015 r. To wtedy, tuż obok zagrożenia ze strony Organizacji Paktu Północnoatlantyckiego oraz Stanów Zjednoczonych Ameryki, za naj- 
większe wyzwania dla rosyjskiego bezpieczeństwa uznano również tzw. kolorowe rewolucje oraz „radykalne społeczne grupy, które używają nacjonalistycznych i religijnych ekstremistycznych ideologii, zagraniczne i międzynarodowe organizacje pozarządowe, jak też prywatnych obywateli, którzy działają przeciwko terytorialnej integralności Rosji i destabilizują procesy polityczne". W odpowiedzi na tak zdefiniowane zagrożenia, w rosyjskim prawodawstwie pojawiły się rozwiązania, które tym wewnętrznym zagrożeniom mają zapobiec. Celem artykułu jest odpowiedź na pytanie, czy rosyjskie władze traktują destabilizację sytuacji wewnętrznej jako jedno z głównych wyzwań dla bezpieczeństwa Rosji, a jeśli tak, to co o tym może świadczyć?

Słowa kluczowe: bezpieczeństwo Rosji; bezpieczeństwo narodowe, strategia bezpieczeństwa Rosji, organizacje pozarządowe, Gwardia Narodowa 